\title{
The Influence of Social Pressure and Nationality on Individual Decisions: Evidence from the Behaviour of Referees
}

\author{
Peter Dawson ${ }^{\dagger}$ and Stephen Dobson ${ }^{\dagger \dagger}$
}

August 2008

\begin{abstract}
This study considers the influences on agents' decisions in an international context. Using data from five seasons of European cup matches it is found that football referees favour home teams when awarding yellow and red cards. Previous research on referee decisions in national leagues has identified social pressure as a key reason for favouritism. While social pressure is also found to be an important influence in this study, the international context reveals that referee decisions are also influenced by the nationality of the referee and club, and the reputation of the league.
\end{abstract}

JEL Classification Codes: D81, L83

Keywords: social pressure, decision-making, referee behaviour, home bias, football

'Department of Economics and International Development, University of Bath, Bath, BA2 7AY, UK, Tel: 44 (0)1225 383074, Email: P.M.Dawson@bath.ac.uk

"Nottingham Trent University 


\section{The Influence of Social Pressure and Nationality on Individual Decisions: Evidence from the Behaviour of Referees}

\section{Introduction}

Team sports are (almost) unique in that the final stage of production (contest between two teams) is observed. This feature presents numerous opportunities for studying the behaviour of agents in sporting contests. One aspect that has received attention is managerial decision making in the form of team selection, substitutions or interchanges (Clement and McCormick, 1989). Another area of interest is the testing of economic hypotheses concerning strategic behaviour by players. In the case of penalty-kicks in football (soccer) for example, a number of studies have found evidence that goalkeepers and penalty-takers adopt mixed strategies (Chiappori et al. 2002; Palacios-Huerta, 2003; Coloma, 2007).

Attention has also focused on the behaviour of match officials (referees). Referees are assigned the task of implementing the laws of the game and ensuring that players abide by the regulations. Research based on match analysis from the European Football Championship in 2000 suggests that a top official makes 137 observable interventions on average during a game, including awarding free-kicks, penalties, corners, throw-ins, and halting play for serious injury (Helsen and Bultynck, 2004). In the case of free-kicks and penalties, the referee has the discretion to decide whether a foul merits a caution, in the form of a yellow or red card. Since some of this decision making is guided by subjective judgment, football referees are often accused of being inconsistent and biased in their decision making (Dawson et al., 2007, Buraimo et al., 2007, Boyko et al., 2007).

Studies of referee decision making in football tend to focus on two decisions: the decision to add on time at the end of matches and/or the decision to award red and yellow cards. Research on a number of domestic European leagues suggests a home team bias in referee decision making 
and identifies social pressure (influence of the crowd) as one of the main reasons for the bias. In contrast, research on North American sports has recently focused on (racial) discrimination in decision making by match officials (see, for example, Price and Wolfers, 2007).

Though referee behaviour has received attention from academics in recent years, little is known about the influences on decisions in an international context ${ }^{1}$. This paper seeks to fill this gap by analysing the decision to award yellow and red cards in European cup football (UEFA Cup and UEFA Champions League). In particular, the study addresses the extent to which social pressure influences the award of red and yellow cards (incidence of disciplinary sanction). In doing this, the roles played by absolute and relative size of the crowd, and the architecture of the stadium (in terms of running tracks and fencing) are considered. The study's international dimension is also exploited by examining the role of nationality in the incidence of disciplinary sanction. To the best of our knowledge, this is the first study to examine the influence of nationality on individual decisions.

The reminder of the paper is structured as follows. Section 2 reviews the previous academic literature. Section 3 describes the data and considers the empirical methodology. Section 4 provides the results and Section 5 concludes.

\section{Literature Review}

Evidence of inconsistency and bias in decision making by referees has been found in a number of European domestic leagues. Garicano et al. (2005), using Spanish data, find a tendency for referees to add on more time at the end of matches when the home team is trailing by one goal compared to when the home team is leading, particularly when contests are close.

\footnotetext{
${ }^{1}$ In a study of the FIFA World Cup, Torgler (2004) observes that a team's probability of winning is increased when a referee is from the same (football) region. However, the impact is only marginally significant and appears to be non-robust.
} 
Similar findings have been demonstrated for the German premier league ( $\left(1^{\text {st }}\right.$ Bundesliga) by Sutter and Kocher (2004) and Dohmen (2008), and for the Italian league by Scoppa (2007).

One potential source of bias by referees is social pressure (influence of the crowd). Dohmen (2008) finds that architectural conditions play a key role in the refereeing bias observed, namely: the size of the crowd (absolute size), the attendance-to-capacity ratio (relative size) and the proximity of supporters to the pitch (the presence of a running track). He finds that there is more added time in close matches when the crowd is physically close to the field of play. Also, home teams are significantly more likely to be awarded a disputed penalty, with the physical distance between the crowd and the playing field important to this decision. Petersson-Lidbom and Priks (2007) find similar results for Italian football following the Italian government’s decision to enforce clubs with sub-standard stadiums to play home games behind closed doors.

Buraimo et al. (2007) and Dawson et al. (2007) consider the impact of social pressure on disciplinary sanction. Buraimo et al. (2007) find the size of the stadium has no statistically significant effect on sanctions awarded to either the home or away team in the English Premier League or in the German Bundesliga. In contrast, Dawson et al. (2007) show that home teams playing in front of larger crowds incur more disciplinary sanctions. Buraimo et al. (2007), in the context of the German Bundesliga, find the presence of a running track increases the number of yellow and red cards awarded to the home team. Neither study, however, considers the impact of relative crowd size.

In a laboratory style setting, Nevill et al. (2002) showed videotapes of tackles to referees who, having been told the identities of the home and away teams, were asked to classify the tackles as legal or illegal. One group of referees viewed the tape with the soundtrack (including the crowd's reaction) switched on, while a second group viewed silently. The first group was 
more likely to rule in favour of the home team (calling, on average, 15.5\% fewer fouls). The first group’s decisions were also more in line with those of the original match referee.

Recent research also suggests that match officials respond to incentives. Rickman and Witt (2008) apply a natural experiment to assess the introduction of professional referees in the English Premier League. They find that home team bias in adding on time at the end of matches essentially disappears following the introduction of professionalism. This is explained in terms of the higher remuneration associated with professional status, which, together with increased monitoring, acts as a disincentive to show (implicit) favouritism.

A popular notion of refereeing inconsistency is the same offence being treated differently by different referees. The fact this occurs suggests officials use prior information to inform the decisions they make. Research has found this to be important both prior to contests taking place and as contests unfold. Plessner and Betsch (2001) observe that officials are less likely to award a penalty to a team if they have previously awarded the same team a penalty but are more likely to award a penalty if they have awarded a penalty to the opposing team. Jones et al. (2002) suggest that a player's aggressive reputation can influence the number of red and yellow cards awarded. For example, on observing a bad challenge by a player with an aggressive reputation, the referee may be more inclined to dismiss that player because he interprets the challenge as a deliberate attempt to injure an opponent. In contrast, a similar challenge made by a player with little or no aggressive reputation may only lead to a caution because the referee believes in this instance, and based on prior knowledge of the player, the tackle was mis-timed rather than intentional ${ }^{2}$.

\footnotetext{
2 The reputation of athletes has also been found to influence the behaviour of judges in individual sports such as boxing (Balmer et al., 2005), ice skating (Findlay and Ste-Marie, 2004) and gymnastics (Ste-Marie and Valiquette, 1996).
} 


\section{Data and Empirical Methodology}

The empirical analysis relates to matches played in the UEFA Champions League and the UEFA Cup over the period 2002-03 to 2006-07³. Match data on home (away) club name, home (away) club nationality, number of yellow and red cards, referee name, referee nationality, date and time of contest, and attendance was provided by UEFA and the UEFA Documentation Center. Data was also gathered for the construction of team rankings (details of which are described below) ${ }^{4}$ and for stadium information pertaining to ground capacity and architecture ${ }^{5}$. In the analysis, all matches played at neutral venues (including finals) are excluded ${ }^{6}$. Following the removal of missing values, there are 1,720 useable observations.

Figures 1 and 2 present frequency graphs of the number of yellow cards incurred by the home and away team by competition. The distributions show that away teams are less likely to incur zero yellow cards compared to home teams and are more likely to incur three or more yellow cards. The pattern is similar across both competitions.

Figures 1 and 2 about here

Tables 1 and 2 show the distribution of yellow and red cards by home and away team. In only $4.63 \%$ of Champions League matches and 3.78\% of UEFA Cup matches were no yellow cards issued to either team. More significantly, in only 24.3\% of Champions League and 26.67\%

\footnotetext{
${ }^{3}$ Both tournaments have undergone a number of format changes in recent times. Currently, both competitions adopt a mix of elimination rounds and round-robin group stage matches, with both using a seeding system to protect the stronger teams from being eliminated in earlier rounds. The total number of teams and the total number of matches played in these competitions has also grown considerably. Prior to 1992, 32 teams competed and a total of 73 matches were played in the European Cup (former name of the Champions League). The corresponding figures for the UEFA Cup were 64 and 126, respectively. By the start of the 2006-07 season, the number of teams competing in the Champions League had more than doubled (to 76 teams) and the total number of games nearly trebled (to 213 games). The number of teams (157) competing and the number of matches played (353) in the UEFA Cup has also increased, although part of this increase is the result of the amalgamation of the UEFA Cup with the European Cup Winners' Cup in 1999.

${ }^{4}$ http://www.xs4all.nl/ kassiesa/bert/uefa/data

${ }^{5}$ http://www.worldstadiums.com/europe/maps/europe.shtml

${ }^{6}$ Examples of matches played at neutral venues include a number of matches involving Israeli teams in 2002-03 and 2006-07. A number of other matches were played in empty stadiums as punishment for crowd trouble. These matches remain in the sample.
} 
of UEFA Cup matches did the home team incur more yellow cards than the away team. It is also notable that the number of yellow cards tends to be higher in the UEFA Cup. Red cards, in contrast, are observed less frequently: less than $20 \%$ of matches in either competition generated one or more red card.

\section{Tables 1 and 2 about here}

Measurement of the dependent variable follows the approach of Dawson et al. (2007). In the estimations below, the dependent variables are the total numbers of disciplinary "points" incurred by the home and away teams in each match, calculated by awarding one point for a yellow card and two points for a red card. Two points are also awarded when a player is dismissed as a result of two cautionable (yellow card) offences in the same match.

In order to establish whether there is systematic bias in either the distribution or incidence of disciplinary sanction, it is necessary to control for relative team quality. In this study, a team quality measure is constructed using historical match data and follows the method of UEFA in the seeding and drawing procedures of the two cup competitions. A team coefficient is calculated as the sum of the number of points of each individual team plus 33\% of the country coefficient ${ }^{7}$. The average coefficient (hereafter referred to as the coefficient index) from the previous five years is used as a measure of team quality.

One weakness of this method is that it does not weight performance according to competition. Further, it is less sophisticated than forecasting models, including ones based on betting data (e.g. Buraimo et al. 2007). Whilst a detailed evaluation of forecasting models is

\footnotetext{
${ }^{7}$ For details on the precise calculations can be found at http://www.xs4all.nl/ kassiesa/bert/uefa/.
} 
beyond the scope of this study, preliminary analysis found that the team coefficient index does a reasonably good job at predicting match outcomes ${ }^{8}$.

In addition to team quality, a variety of other controls are also included, based on the discussion in Sections 1 and 2. These include variables relating to crowd size, crowd density (attendance to capacity ratio) and stadium architecture (i.e. presence of a running track and/or fencing), competition (Champions League or UEFA Cup) and stage of competition. The nationality of the referee and the nationality of the club are also used as controls. Definitions of the variables used in this study are provided in the Appendix.

The number of disciplinary points per match takes the form of count data, which suggests the use of a count data regression model ${ }^{9}$. However, it is also possible to model count data using discrete choice methods that recognise the sequential nature of the data (Cameron and Trivedi, 2005). One such candidate is the ordered probit model, hence:

$\begin{aligned} y_{h}^{*} & =\mathbf{X}^{\prime} \boldsymbol{\beta}_{h}+\boldsymbol{\varepsilon}_{h} \\ y_{a}^{*} & =\mathbf{X}^{\prime} \boldsymbol{\beta}_{a}+\boldsymbol{\varepsilon}_{a}\end{aligned}$

Where the subscripts " $h$ " and "a” refer to the home team and away team, respectively. $y_{h}^{*}$ and $y_{a}^{*}$ are constructed according to the following criteria:

\footnotetext{
${ }^{8}$ Binary probit and ordered probit models were constructed with the team coefficient index as the explanatory variable. In the majority of cases it was found that a one unit increase in rank difference is predicted to increase the probability of a home win by approximately $2 \%$, which seems intuitively plausible. Also, with the exception of Dawson et al. (2007) and Buraimo et al. (2007), previous studies have used relatively simple measures to capture team quality.

${ }^{9}$ For example, Dawson et al. (2007) use zero-inflated Poisson and negative binomial regression models.
} 


$$
y_{h}=\left\{\begin{array}{l}
0 \text { if } y_{h}^{*}=0 \\
1 \text { if } y_{h}^{*}=1 \\
2 \text { if } y_{h}^{*}=2 \\
3 \text { if } y_{h}^{*}=3 \\
4 \text { if } y_{h}^{*}=4 \\
5 \text { if } y_{h}^{*} \geq 5
\end{array} \quad y_{a}=\left\{\begin{array}{l}
0 \text { if } y_{a}^{*}=0 \\
1 \text { if } y_{a}^{*}=1 \\
2 \text { if } y_{a}^{*}=2 \\
3 \text { if } y_{a}^{*}=3 \\
4 \text { if } y_{a}^{*}=4 \\
5 \text { if } y_{a}^{*} \geq 5
\end{array}\right.\right.
$$

Each endogenous discrete variable is associated with $\mathbf{X}$ exogenous variables and coefficients $\boldsymbol{\beta}_{\mathrm{h}}$ $\beta_{\mathrm{a}}$ as described above. If $\varepsilon_{\mathrm{h}}$ and $\varepsilon_{\mathrm{a}}$ are assumed to be independent and normally distributed, (1) can be estimated using a univariate ordered probit model. A bivariate ordered probit model is required if $\varepsilon_{\mathrm{h}}$ and $\varepsilon_{\mathrm{a}}$ are assumed to be joint normal ${ }^{10}$ and $\operatorname{Cov}\left(\varepsilon_{h}, \varepsilon_{a}\right)=\rho$. Thus, the univariate model can be considered a special case of the bivariate model, where $\rho=0$. Both univariate and bivariate models are estimated using the method of maximum likelihood.

\section{Results}

Table 3 presents results for the determinants of disciplinary points based on univariate and bivariate ordered probit models. In the univariate model, the home team equation shows that the difference in the team coefficient index (home coefficient index minus away coefficient index) is negative and statistically significant. This implies that a strong home team will incur fewer disciplinary points. For the away team, the coefficient is correctly signed (positive) but is not statistically significant. In both the home and away equations it appears that, on average and

${ }^{10} E\left(\varepsilon_{h}\right)=E\left(\varepsilon_{a}\right)=0, \operatorname{Var}\left(\varepsilon_{h}\right)=\operatorname{Var}\left(\varepsilon_{a}\right)=1$ 
other things unchanged, the number of disciplinary points is lower in the Champions League. However, there is also evidence, for both teams, that the number of disciplinary points increases as the competitions enter the final phases. In terms of the influence of the crowd and the architecture of the stadium, it appears that relative size of the crowd matters more than the absolute size: the away team is likely to incur more disciplinary points the closer the stadium is to capacity. The presence of a running track has the effect of increasing the number of disciplinary points awarded to the home team.

\section{Table 3 about here}

The findings associated with the impact of the crowd and the architecture of the stadium are consistent with previous research. The presence of a running track increases the distance between the pitch and the crowd. This works to increase the number of disciplinary points awarded to the home team, implying less implicit favouritism towards the home team when the influence of social pressure is weaker. On the other hand, the relative size of the crowd appears to work in the opposite way, by increasing the number of disciplinary points awarded to the away team. The absolute size of the crowd and the presence of fencing have no impact.

One criticism of the univariate approach is that it assumes no correlation between the home and away team equations. Buraimo et al. (2007), in their study of the German Bundesliga and the English Premier League, find that a yellow card previously awarded to the home (away) team increases the probability of the away (home) team receiving a similar sanction. As the authors suggest, this could reflect retaliation by players or the tendency for referees to "even-up” decisions. To allow for this possibility, a bivariate ordered probit model is also estimated. The significance of the $\rho$ statistic and the LR test of independent equations provide strong evidence 
that the error terms in the two equations are correlated, and justifies the use of a bivariate model. However, the coefficients are virtually indistinguishable.

A unique feature of this study is the opportunity to test for the influence of nationality on decisions. In European cup football, referees are assigned to matches according to Article 19.02 of the Regulations of the Champions League and UEFA Cup ${ }^{11}$. Generally, referees cannot be from the same football association as the two teams competing in the contest. Given this, home nation bias should be of limited concern. However, this does not preclude the possibility of variation in referee behaviour by nationality. Nor does it preclude the possibility that referees form judgements about teams and nations ${ }^{12}$.

Table 4 reports bivariate ordered probit estimates under a variety of different specifications. Model (1) includes club nationality fixed effects alongside referee nationality effects. The inclusion of club nationality results in the team coefficient index becoming insignificant, so it appears that club effects are capturing some (most) of the impact of team quality. The stage of the competition becomes insignificant in the home team equation and less significant in the away team equation. Champions League matches (home equation and away equation), the presence of a running track (home equation only), and the relative size of the crowd (away equation only) remain important determinants of the incidence of disciplinary sanction.

\footnotetext{
${ }^{11}$ The Referees Committee, in cooperation with the UEFA administration, appoints a referee, two assistant referees and a fourth official for each match. Only referees whose names appear on the official FIFA list of referees are eligible. The fourth official and assistant referees are, in principle, proposed by the national association of the referee, in accordance with criteria established by the Referees Committee.

${ }^{12}$ In the 2006 World Cup Finals there were numerous complaints and allegations of referee bias in favour of the larger, well-established teams. During the 2002 tournament, held jointly by South Korea (Korea Republic) and Japan, there were allegations of favouritism towards the host nations - specifically when South Korea played, and subsequently defeated, Italy in the Second Round. During the European 2004 Championship the Portuguese media criticised the appointment of the German referee Merkus Merk for a game involving Portugal and Greece, claiming that he would favour Greece because they were coached by a German national. The Romanian Football Association has also claimed discrimination against their national team (and other Eastern European countries) when involved in games against teams from more established associations.
} 
In Model (2) club nationality fixed effects are replaced with variables denoting whether the home or away teams (or both) is from one of the "big five” leagues (England, Italy, Germany, Spain and France). This is designed to capture possible "league reputation” effects, whereby a team from one of the big five leagues is likely to incur fewer disciplinary points. As expected, a home team from the "big five" incurs fewer disciplinary points if playing a team from outside the "big five" but the coefficient is not statistically significant. The effect is significant for an away team from one of the big five leagues. Also, more disciplinary points are awarded to the home team and away team if they are both drawn from one of the big five leagues. It would appear therefore that these variables are also capturing the quality of the teams involved in the contest.

\section{Table 4 about here}

A dummy variable, capturing whether the referee officiated at the 2004 European Championships (defined here as an "elite" referee), is included in Model (3). A positive impact is found in both the home and away team equations (Models (3) and (4)) but there is no significant difference. A possible interpretation is that elite referees compensate for inherent (implicit) favouritism by issuing more disciplinary sanctions to the home team, though this conclusion must be tentative as there may be problems associated with sample selection effects.

A sensitivity analysis, in the form of a separate analysis for yellow cards, is provided in Table 5. In general, the coefficients are less significant compared to the disciplinary points models. However, it is possible to control for an additional feature in these specifications, namely the extent to which red card offences relate to yellow card offences. Here evidence is found of simultaneity between the award of red cards and yellow cards: teams that are punished for red card offences also tend to incur more yellow cards.

Table 5 also provides a further sensitivity test through the inclusion of within game parameters for Champions League matches only. A series of variables are included relating to 
possession, shots on goal and number of fouls committed. With the exception of number of fouls, none of these factors are significant. Moreover, previous variables remain reasonably robust to the inclusion of these additional variables.

\section{Table 5 about here}

Finally, the marginal effect of referee nationality is presented in Table 6. A priori, and given the above discussions, it might be expected that referees from the more prominent associations (England, France, Germany, Italy and Spain) will be less prone to implicit favouritism compared to referees from other associations. There appears to be some evidence to support this since officials from Belgium, Holland, Norway, Russia and Sweden tend to award fewer disciplinary points to the home team. However, Belgian, Dutch, Russian and Swedish referees also tend to issue fewer disciplinary points to the away team. There are also some interesting anomalies in the data. Portuguese officials issue more disciplinary points to the away team. On the other hand, Greek officials tend to issue more sanctions (to both the home and away teams) compared to anyone else.

\section{Table 6 about here}

The precise role of nationality in influencing referee decisions is difficult to identify not least because of the interplay between referee and team nationality, and team reputation. Akerlof (1997) and Akerlof and Kranton (2000) suggest that individual decisions are influenced by one’s own identity and the perception of others. This notion seems particularly relevant in the present context since football referees, much like officials in many other sports, are required to make split-second decisions under uncertainty. Faced with a key (and possibly contentious) decision, the results of this study suggest a referee is likely to be influenced not only by the crowd but also by his perception of the quality, and nationality, of the teams involved in the contest. 


\section{Conclusion}

This study has considered the influences on agents' decisions in an international context. Using data from European cup matches, it is found that football referees tend to favour home teams when disciplining players. Consistent with previous work, social pressure is an important influence on behaviour, with crowd density and stadium architecture playing important roles. The incidence of disciplinary sanction is also influenced by the type and stage of the competition. The international context for this study allows a further dimension to referee decisions to be investigated, namely the role played by nationality. Of particular interest is the finding that nationality influences individual decisions.

Referees are required to make split-second decisions. Faced with significant time pressure, individuals tend to focus on salient cues in forming a decision. Dohmen (2008) and Sutter and Kocher (2004) argue that in the case of football referees, crowd noise is the salient cue. This analysis confirms that crowd noise is important but also suggests that in an international context decisions are also influenced by referee nationality, team nationality and league reputation. 


\section{Acknowledgements}

The authors gratefully acknowledge UEFA and the UEFA Documentation Center in particular for providing the data. The views expressed here represent the views of the authors and not the views of UEFA or any of its employees. We would also like to thank Christos Papahristodoulou for providing the match-play statistics from the Champions League tournament and the research assistance of Joseph Birch. The usual disclaimer applies. 


\section{References}

Akerlof, G.A (1997). Social distance and social decisions. Econometrica 65, 1005-1027.

Akerlof, G.A. and Kranton, R. (2000). Economics and identity. Quarterly Journal of Economics 115, 715-753.

Balmer, N.J., Nevill, A.M. and Lane, A.M. (2005). Do judges enhance home advantage in European Championship Boxing? Journal of Sports Sciences 23, 409-416.

Boyko, R.H., Boyko, A.R. and Boyko, M.G. (2007). Referee bias contributes to home advantage in English Premiership football. Journal of Sports Sciences 25, 1185-1194.

Buraimo, B., Forrest, D. and Simmons, R. (2007). The twelfth man? Refereeing bias in England and German soccer. International Association of Sports Economists Working Paper 0707.

Cameron, A.C. and Trivedi, P.K. (2005). Microeconometrics: Methods and Applications. Cambridge University Press, New York.

Chiappori, P.-A., Levitt, S., and Groseclose, T. (2002). Testing mixed-strategy equilibria when players are heterogeneous: The case of penalty kicks in soccer. American Economic Review 92, 1138-1151.

Clement, R.C. and McCormick, R.E. (1989). Coaching team production. Economic Inquiry 27, 287-304. 
Coloma, G. (2007). Penalty kicks in soccer. An alternative methodology for testing mixedstrategy equilibria. Journal of Sports Economics 8, 530-545.

Dawson, P., Dobson, S., Goddard, J. and Wilson, J. (2007). Are football referees really biased and inconsistent? Evidence from the English Premier League. Journal of the Royal Statistical Society, Series A 170, 231-250.

Dohmen, T.J. (2008). The influence of social forces: Evidence from the behavior of football referees. Forthcoming in Economic Inquiry. Published online January 2008.

Findlay, L.C. and Ste-Marie, D.M. (2004). A reputation bias in figure skating judging. Journal of Sport and Exercise Psychology 26, 154-166.

Garicano, L., I. Palacios-Huerta, and C. Prendergast (2005). Favoritism under social pressure. Review of Economics and Statistics 87, 208-216.

Helsen, W., \& Bultynck, J. B. (2004). Physical and perceptual cognitive demands of top-class refereeing in association football. Journal of Sports Sciences 22, 179-189.

Jones, M.V., Paull, G.C. and Erskine, J. (2002). The impact of a team's aggressive reputation on the decisions of association football referees. Journal of Sports Sciences 20, 991-1000. 
Nevill, A.M., Balmer, N.J. and Williams, A.M. (2002). The influence of crowd noise and experience upon refereeing decisions in football. Psychology of Sport and Exercise 3, 261-272.

Palacios-Huerta, I. (2003). Professionals play minimax. Review of Economic Studies 70, 395-415.

Pettersson-Lidbom, P. and Priks, M. (2007). Behavior under social pressure: empty Italian stadiums and referee bias. CESifo Working Paper 1960.

Plessner, H. and Betsch, T. (2001). Sequential effects in important referee decisions: the case of penalties in soccer. Journal of Sport and Exercise Psychology 23, 254-259.

Price, J. and Wolfers, J. (2007). Racial discrimination among NBA referees. National Bureau of Economic Research, Working Paper No.13206.

Rickman, N. and Witt, R. (2008). Favouritism and financial incentives: a natural experiment. Economica 75, 296-309.

Scoppa (2007). Are subjective evaluations biased by social factors or connections? An econometric analysis of soccer referee decisions. Empirical Economics (forthcoming). Published online June 2007.

Ste-Marie, D.M., \& Valiquette, S.M. (1996). Enduring memory-induced biases in gymnastic judging. Journal of Experimental Psychology: Learning, Memory, and Cognition 22, 1498-1502. 
Sutter, M. and Kocher, M.G. (2004). Favoritism of agents - the case of referees' home bias. Journal of Economic Psychology 25, 461-469.

Torgler, B. (2004). The economics of the FIFA football World Cup. Kyklos 57, 287-300. 
Figure 1: Frequency Distribution of Home Yellow Cards by Competition

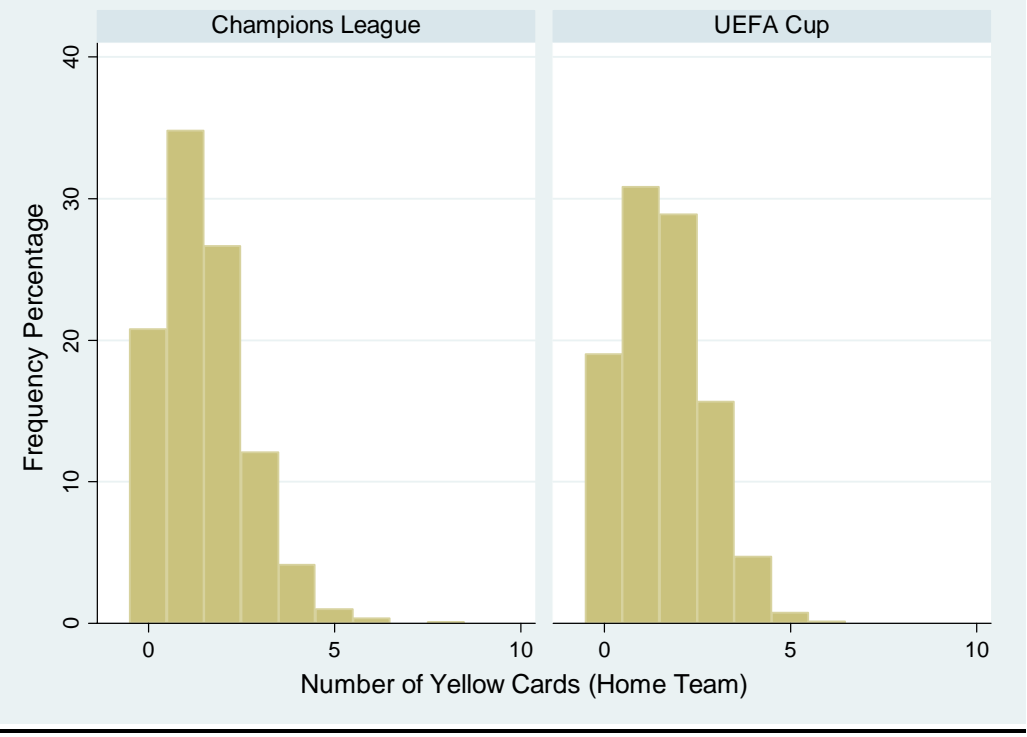

Figure 2: Frequency Distribution of Away Yellow Cards by Competition

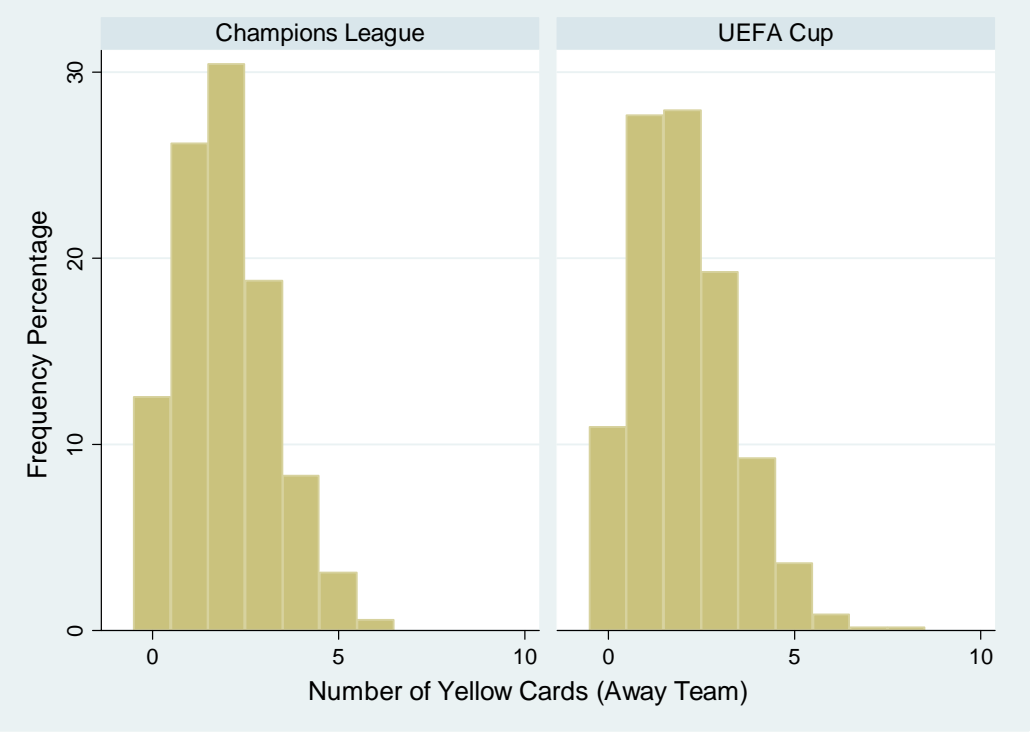


Table 1: Cross-Tabulation of Yellow Cards Issued to Home and Away Teams (by Competition)

\begin{tabular}{|l|l|l|l|l|l|l|l|l|}
\hline $\begin{array}{l}\text { Home } \\
\text { Yellow }\end{array}$ & \multicolumn{7}{|c|}{ Away Yellow } & Total \\
\hline & 0 & 1 & 2 & 3 & 4 & 5 & 6 & \\
\hline 0 & 4.63 & 6.52 & 5.67 & 2.27 & 0.95 & 0.76 & 0 & $\mathbf{2 0 . 7 9}$ \\
\hline 1 & 3.59 & 9.64 & 11.15 & 6.52 & 3.31 & 0.38 & 0.19 & $\mathbf{3 4 . 7 8}$ \\
\hline 2 & 2.46 & 6.43 & 8.98 & 5.48 & 1.98 & 1.13 & 0.09 & $\mathbf{2 6 . 6 5}$ \\
\hline 3 & 1.23 & 2.74 & 3.12 & 3.40 & 1.13 & 0.38 & 0.09 & $\mathbf{1 2 . 1 0}$ \\
\hline 4 & 0.66 & 0.76 & 0.95 & 0.95 & 0.57 & 0.19 & 0 & 4.16 \\
\hline 5 & 0 & 0.09 & 0.38 & 0.09 & 0.19 & 0.28 & 0 & $\mathbf{1 . 0 4}$ \\
\hline 6 & 0 & 0 & 0.19 & 0 & 0.19 & 0 & 0 & $\mathbf{0 . 3 8}$ \\
\hline 7 & 0 & 0 & 0 & 0 & 0 & 0 & 0 & $\mathbf{0}$ \\
\hline 8 & 0 & 0 & 0 & 0.09 & 0 & 0 & 0 & $\mathbf{0 . 0 9}$ \\
\hline Total & $\mathbf{1 2 . 5 7}$ & $\mathbf{2 6 . 1 8}$ & $\mathbf{3 0 . 4 3}$ & $\mathbf{1 8 . 8 1}$ & $\mathbf{8 . 3 2}$ & $\mathbf{3 . 1 2}$ & $\mathbf{0 . 5 7}$ & $\mathbf{1 0 0 . 0 0}$ \\
\hline
\end{tabular}

Panel (a): Champions League

\begin{tabular}{|l|l|l|l|l|l|l|l|l|l|l|}
\hline $\begin{array}{l}\text { Home } \\
\text { Yellow }\end{array}$ & \multicolumn{9}{|c|}{ Away Yellow } & Total \\
\hline & 0 & 1 & 2 & 3 & 4 & 5 & 6 & 7 & 8 & \\
\hline 0 & 3.78 & 6.10 & 5.35 & 2.52 & 0.94 & 0.25 & 0.06 & 0 & 0 & $\mathbf{1 9 . 0 1}$ \\
\hline 1 & 3.84 & 9.88 & 7.17 & 5.98 & 2.83 & 0.88 & 0.13 & 0.06 & 0.06 & $\mathbf{3 0 . 8 4}$ \\
\hline 2 & 2.45 & 7.05 & 8.75 & 6.23 & 2.83 & 1.13 & 0.31 & 0.06 & 0.06 & $\mathbf{2 8 . 8 9}$ \\
\hline 3 & 0.63 & 3.65 & 4.47 & 3.52 & 2.14 & 0.94 & 0.19 & 0.06 & 0.06 & $\mathbf{1 5 . 6 7}$ \\
\hline 4 & 0.25 & 0.76 & 1.83 & 0.88 & 0.44 & 0.38 & 0.19 & 0 & 0 & $\mathbf{4 . 7 2}$ \\
\hline 5 & 0 & 0.25 & 0.25 & 0.13 & 0.06 & 0.06 & 0 & 0 & 0 & $\mathbf{0 . 7 6}$ \\
\hline 6 & 0 & 0 & 0.13 & 0 & 0 & 0 & 0 & 0 & 0 & $\mathbf{0 . 1 3}$ \\
\hline Total & $\mathbf{1 0 . 9 5}$ & $\mathbf{2 7 . 6 9}$ & $\mathbf{2 7 . 9 4}$ & $\mathbf{1 9 . 2 6}$ & $\mathbf{9 . 2 5}$ & $\mathbf{3 . 6 5}$ & $\mathbf{0 . 8 8}$ & $\mathbf{0 . 1 9}$ & $\mathbf{0 . 1 9}$ & $\mathbf{1 0 0 . 0 0}$ \\
\hline
\end{tabular}

Panel (b): UEFA Cup 
Table 2: Cross-Tabulation of Red Cards Issued to Home and Away Teams (by Competition)

\begin{tabular}{|l|l|l|l|l|l|l|l|l|}
\hline & \multicolumn{3}{|c|}{ Champions League } & \multicolumn{3}{c|}{ UEFA Cup } \\
\hline $\begin{array}{l}\text { Red } \\
\text { Card } \\
\text { Home }\end{array}$ & \multicolumn{7}{|c|}{ Red Card Away } & \multicolumn{3}{c|}{} \\
\hline & 0 & 1 & 2 & Total & 0 & 1 & 2 & Total \\
\hline 0 & 82.89 & 9.74 & 0.95 & $\mathbf{9 3 . 5 7}$ & 81.31 & 9.13 & 0.82 & $\mathbf{9 1 . 2 5}$ \\
\hline 1 & 5.10 & 0.85 & 0 & $\mathbf{5 . 9 5}$ & 6.54 & 1.57 & 0.13 & $\mathbf{8 . 2 4}$ \\
\hline 2 & 0.19 & 0.28 & 0 & $\mathbf{0 . 4 7}$ & 0.13 & 0.25 & 0.06 & $\mathbf{0 . 4 4}$ \\
\hline 3 & 0 & 0 & 0 & $\mathbf{0}$ & 0.06 & 0 & 0 & $\mathbf{0 . 0 6}$ \\
\hline Total & $\mathbf{8 8 . 1 9}$ & $\mathbf{1 0 . 8 7}$ & $\mathbf{0 . 9 5}$ & $\mathbf{1 0 0 . 0 0}$ & $\mathbf{8 8 . 0 4}$ & $\mathbf{1 0 . 9 5}$ & $\mathbf{1 . 0 1}$ & $\mathbf{1 0 0 . 0 0}$ \\
\hline
\end{tabular}


Table 3: Univariate and Bivariate Ordered Probit Estimates

\begin{tabular}{|c|c|c|c|c|}
\hline & \multicolumn{2}{|c|}{ Univariate Ordered Probit } & \multicolumn{2}{|c|}{ Bivariate Ordered Probit } \\
\hline & Home Team & Away Team & Home Team & Away Team \\
\hline \multicolumn{5}{|l|}{ Variables } \\
\hline $\begin{array}{l}\text { Difference in } \\
\text { Team Coefficient } \\
\text { Index }\end{array}$ & $-0.008^{* *}(0.003)$ & $0.002(0.003)$ & $-0.008^{* *}(0.003)$ & $0.002(0.003)$ \\
\hline $\begin{array}{l}\text { Stage of } \\
\text { Competition }\end{array}$ & $0.113 *(0.060)$ & $0.150 * *(0.060)$ & $0.114 *(0.060)$ & $0.149 * *(0.060)$ \\
\hline $\begin{array}{l}\text { Champions } \\
\text { League }\end{array}$ & $-0.199 * * *(0.069)$ & $-0.187^{* * *}(0.068)$ & $-0.199 * * *(0.069)$ & $-0.188^{* * *}(0.068)$ \\
\hline Attendance / 1000 & $0.0003(0.002)$ & $0.002(0.002)$ & $0.0003(0.002)$ & $0.002(0.002)$ \\
\hline $\begin{array}{l}\text { Attendance to } \\
\text { Capacity Ratio }\end{array}$ & $0.072(0.093)$ & $0.232 * *(0.093)$ & $0.073(0.093)$ & $0.231^{* *}(0.093)$ \\
\hline Track & $0.185^{* * *}(0.059)$ & $0.019(0.059)$ & $0.185^{* * *}(0.059)$ & $0.019(0.059)$ \\
\hline Fence & $0.101(0.066)$ & $-0.013(0.065)$ & $0.101(0.066)$ & $-0.012(0.065)$ \\
\hline $\begin{array}{l}\text { Referee } \\
\text { Nationality Fixed } \\
\text { Effects }\end{array}$ & INCLUDED & INCLUDED & INCLUDED & INCLUDED \\
\hline Rho $(\rho)$ & & & \multicolumn{2}{|c|}{$0.241^{* * *}(0.025)$} \\
\hline \multicolumn{5}{|l|}{ Thresholds } \\
\hline Cut1 & $-0.924 * * *(0.077)$ & $-1.174 * * *(0.079)$ & $-0.924 * * *(0.077)$ & $-1.176^{* * *}(0.079)$ \\
\hline Cut2 & $-0.031(0.075)$ & $-0.316^{* * *}(0.075)$ & $-0.028(0.075)$ & $-0.314 * * *(0.075)$ \\
\hline Cut3 & $0.727 * * *(0.076)$ & $0.384 * * *(0.075)$ & $0.728 * * *(0.076)$ & $0.388 * * *(0.075)$ \\
\hline Cut4 & $1.366^{* * *}(0.081)$ & $0.963 * * *(0.077)$ & $1.363^{* * *}(0.081)$ & $0.964 * * *(0.077)$ \\
\hline Cut5 & $1.847 * * *(0.090)$ & $1.484^{* * *}(0.081)$ & $1.840 * * *(0.090)$ & $1.481^{* * *}(0.081)$ \\
\hline Pseudo- $^{2}$ & 0.013 & 0.013 & \multirow{2}{*}{\multicolumn{2}{|c|}{69.57}} \\
\hline $\begin{array}{l}\text { LR test (joint } \\
\text { significance of } \\
\text { covariates) }\end{array}$ & 69.68 & 75.63 & & \\
\hline $\begin{array}{l}\text { LR test } \\
\text { (independent } \\
\text { equations) }\end{array}$ & & & \multicolumn{2}{|c|}{87.34} \\
\hline $\mathrm{N}$ & 1720 & 1720 & \multicolumn{2}{|c|}{1720} \\
\hline
\end{tabular}

Notes: Standard errors in parentheses. ${ }^{* * *},{ }^{* *},{ }^{*}$, significant at $1 \%, 5 \%$ and $10 \%$ levels, respectively (twotailed tests. 
$\underline{\text { Table 4: Referee Nationality, Club Nationality and "League Reputation" Effects }}$

\begin{tabular}{|c|c|c|c|c|}
\hline & \multicolumn{4}{|c|}{ Bivariate Ordered Probit Estimates } \\
\hline Variables & (1) & (2) & (3) & (4) \\
\hline \multicolumn{5}{|l|}{ Home Team } \\
\hline $\begin{array}{l}\text { Difference in Team } \\
\text { Coefficient Index }\end{array}$ & $0.0002(0.004)$ & $-0.0001(0.003)$ & $0.001(0.004)$ & $0.0005(0.004)$ \\
\hline $\begin{array}{l}\text { Stage of } \\
\text { Competition }\end{array}$ & $0.080(0.065)$ & $0.098(0.063)$ & $0.062(0.066)$ & $0.047(0.066)$ \\
\hline Champions League & $-0.217 * * *(0.074)$ & $-0.213 * * *(0.070)$ & $-0.259 * *(0.076)$ & $-0.272 * * *(0.076)$ \\
\hline Attendance / 1000 & $0.0002(0.002)$ & $0.001(0.002)$ & $-0.0002(0.002)$ & $-0.0002(0.002)$ \\
\hline $\begin{array}{l}\text { Attendance to } \\
\text { Capacity Ratio }\end{array}$ & $0.150(0.100)$ & $0.040(0.094)$ & $0.158(0.10)$ & $0.166 *(0.100)$ \\
\hline Track & $0.142 * *(0.065)$ & $0.177 * * *(0.059)$ & $0.145^{* * *}(0.065)$ & $0.143 * *(0.065)$ \\
\hline Fence & $0.022(0.072)$ & $0.096(0.066)$ & $0.021(0.072)$ & $0.022(0.072)$ \\
\hline Big Five Home & & $-0.322 * * *(0.075)$ & & $-0.258 * *(0.122)$ \\
\hline Big Five Away & & $0.089(0.074)$ & & $0.314^{* * *}(0.120)$ \\
\hline $\begin{array}{l}\text { Big Five Home x } \\
\text { Big Five Away }\end{array}$ & & $0.296 * * *(0.103)$ & & $0.290 * * *(0.105)$ \\
\hline Elite Referee & & & $0.190 * *(0.087)$ & $0.173 * *(0.087)$ \\
\hline \multicolumn{5}{|l|}{ Away Team } \\
\hline $\begin{array}{l}\text { Difference in Team } \\
\text { Coefficient Index }\end{array}$ & $0.0013(0.004)$ & $0.0001(0.003)$ & $0.002(0.004)$ & $0.001(0.004)$ \\
\hline $\begin{array}{l}\text { Stage of } \\
\text { Competition }\end{array}$ & $0.121 *(0.064)$ & $0.138 * *(0.063)$ & $0.110 *(0.065)$ & $0.097(0.065)$ \\
\hline Champions League & $-0.207 * * *(0.073)$ & $-0.198 * * *(0.069)$ & $-0.233 * * *(0.075)$ & $-0.244 * * *(0.075)$ \\
\hline Attendance / 1000 & $0.003(0.002)$ & $0.002(0.002)$ & $0.002(0.002)$ & $0.002(0.002)$ \\
\hline $\begin{array}{l}\text { Attendance to } \\
\text { Capacity Ratio }\end{array}$ & $0.273 * * *(0.099)$ & $0.251 * * *(0.093)$ & $0.278 * * *(0.099)$ & $0.285 * * *(0.099)$ \\
\hline Track & $0.064(0.064)$ & 0.017 (0.059) & $0.066(0.064)$ & $0.064(0.064)$ \\
\hline Fence & $0.022(0.071)$ & $-0.007(0.066)$ & $0.021(0.071)$ & $0.022(0.071)$ \\
\hline Big Five Home & & $-0.053(0.074)$ & & $-0.053(0.121)$ \\
\hline Big Five Away & & $-0.169 * *(0.074)$ & & $-0.012(0.120)$ \\
\hline $\begin{array}{l}\text { Big Five Home x } \\
\text { Big Five Away }\end{array}$ & & $0.255 * *(0.102)$ & & $0.272 * * *(0.104)$ \\
\hline Elite Referee & & & $0.116(0.086)$ & $0.100(0.086)$ \\
\hline $\begin{array}{l}\text { Referee Nationality } \\
\text { Fixed Effects }\end{array}$ & INCLUDED & INCLUDED & INCLUDED & INCLUDED \\
\hline $\begin{array}{l}\text { Team Nationality } \\
\text { Fixed Effects }\end{array}$ & INCLUDED & NOT INCLUDED & INCLUDED & INCLUDED \\
\hline Rho $(\rho)$ & $0.254 * * *(0.025)$ & $0.244 * * *(0.025)$ & $0.252 * * *(0.025)$ & $0.249 * * *(0.025)$ \\
\hline $\begin{array}{l}\text { LR test (joint } \\
\text { significance of } \\
\text { covariates) }\end{array}$ & 167.30 & 102.67 & 171.88 & 179.30 \\
\hline $\begin{array}{l}\text { LR test } \\
\text { (independent } \\
\text { equations) }\end{array}$ & 96.40 & 89.92 & 95.31 & 92.84 \\
\hline $\mathrm{N}$ & 1720 & 1720 & 1720 & 1720 \\
\hline
\end{tabular}

Notes: As Table 3. 
Table 5: Sensitivity Analysis - Yellow Cards and "Within-Game" Dynamics

\begin{tabular}{|c|c|c|c|c|c|c|}
\hline \multirow[b]{2}{*}{ Variables } & \multicolumn{2}{|c|}{$\begin{array}{l}\text { Model 1: Yellow Cards } \\
\text { Only }\end{array}$} & \multicolumn{2}{|c|}{$\begin{array}{c}\text { Model 2: "Within Game" } \\
\text { Dynamics }\end{array}$} & \multicolumn{2}{|c|}{$\begin{array}{c}\text { Model 3: "Within Game" } \\
\text { Dynamics }\end{array}$} \\
\hline & $\begin{array}{l}\text { Home } \\
\text { Equation }\end{array}$ & $\begin{array}{l}\text { Away } \\
\text { Equation }\end{array}$ & $\begin{array}{l}\text { Home } \\
\text { Equation }\end{array}$ & $\begin{array}{c}\text { Away } \\
\text { Equation }\end{array}$ & $\begin{array}{l}\text { Home } \\
\text { Equation }\end{array}$ & $\begin{array}{c}\text { Away } \\
\text { Equation }\end{array}$ \\
\hline $\begin{array}{l}\text { Difference in Team } \\
\text { Coefficient Index }\end{array}$ & $\begin{array}{l}-0.0004 \\
(0.004)\end{array}$ & $\begin{array}{l}0.002 \\
(0.004)\end{array}$ & $\begin{array}{l}0.006 \\
(0.006)\end{array}$ & $\begin{array}{c}0.007 \\
(0.006)\end{array}$ & $\begin{array}{l}0.009 \\
(0.006)\end{array}$ & $\begin{array}{l}0.004 \\
(0.006)\end{array}$ \\
\hline Stage of Competition & $\begin{array}{l}0.031 \\
(0.066)\end{array}$ & $\begin{array}{l}0.099 \\
(0.065)\end{array}$ & $\begin{array}{l}-0.083 \\
(0.115)\end{array}$ & $\begin{array}{l}0.010 \\
(0.114)\end{array}$ & $\begin{array}{l}-0.143 \\
(0.116)\end{array}$ & $\begin{array}{l}-0.037 \\
(0.115)\end{array}$ \\
\hline Champions League & $\begin{array}{l}-0.252^{* * *} \\
(0.077)\end{array}$ & $\begin{array}{l}-0.220^{* * *} \\
(0.076)\end{array}$ & & & & \\
\hline Attendance / 1000 & $\begin{array}{l}-0.00002 \\
(0.002)\end{array}$ & $\begin{array}{l}0.002 \\
(0.002)\end{array}$ & $\begin{array}{l}-0.002 \\
(0.003)\end{array}$ & $\begin{array}{l}-0.005 \\
(0.003)\end{array}$ & $\begin{array}{l}-0.003 \\
(0.003)\end{array}$ & $\begin{array}{l}-0.005 \\
(0.003)\end{array}$ \\
\hline $\begin{array}{l}\text { Attendance to Capacity } \\
\text { Ratio }\end{array}$ & $\begin{array}{l}0.142 \\
(0.100)\end{array}$ & $\begin{array}{l}0.241^{* *} \\
(0.099)\end{array}$ & $\begin{array}{l}0.370 \\
(0.337)\end{array}$ & $\begin{array}{l}0.919 * * * \\
(0.337)\end{array}$ & $\begin{array}{l}0.281 \\
(0.342)\end{array}$ & $\begin{array}{l}1.095^{* * *} \\
(0.343)\end{array}$ \\
\hline Track & $\begin{array}{l}0.100 \\
(0.065)\end{array}$ & $\begin{array}{l}0.070 \\
(0.065)\end{array}$ & $\begin{array}{l}0.113 \\
(0.125)\end{array}$ & $\begin{array}{l}0.223^{*} \\
(0.125)\end{array}$ & $\begin{array}{l}0.124 \\
(0.127)\end{array}$ & $\begin{array}{l}0.194 \\
(0.127)\end{array}$ \\
\hline Fence & $\begin{array}{l}0.039 \\
(0.072)\end{array}$ & $\begin{array}{l}0.008 \\
(0.072)\end{array}$ & $\begin{array}{l}0.085 \\
(0.130)\end{array}$ & $\begin{array}{l}-0.190 \\
(0.129)\end{array}$ & $\begin{array}{l}-0.003 \\
(0.133)\end{array}$ & $\begin{array}{l}-0.114 \\
(0.132)\end{array}$ \\
\hline Big Five Home & $\begin{array}{l}-0.298 * * \\
(0.123)\end{array}$ & $\begin{array}{l}-0.034 \\
(0.121)\end{array}$ & $\begin{array}{l}-0.202 \\
(0.217)\end{array}$ & $\begin{array}{l}-0.266 \\
(0.216)\end{array}$ & $\begin{array}{l}-0.154 \\
(0.222)\end{array}$ & $\begin{array}{l}-0.289 \\
(0.221)\end{array}$ \\
\hline Big Five Away & $\begin{array}{l}0.060 \\
(0.113)\end{array}$ & $\begin{array}{l}-0.366^{* * *} \\
(0.112)\end{array}$ & $\begin{array}{l}0.384^{*} \\
(0.216)\end{array}$ & $\begin{array}{l}0.530^{* *} \\
(0.216)\end{array}$ & $\begin{array}{l}0.292 \\
(0.221)\end{array}$ & $\begin{array}{l}0.563^{* *} \\
(0.221)\end{array}$ \\
\hline $\begin{array}{l}\text { Big Five Home x Big } \\
\text { Five Away }\end{array}$ & $\begin{array}{l}0.339 * * * \\
(0.106)\end{array}$ & $\begin{array}{l}0.299 * * * \\
(0.104)\end{array}$ & $\begin{array}{l}0.541 * * * \\
(0.185)\end{array}$ & $\begin{array}{l}0.195 \\
(0.183)\end{array}$ & $\begin{array}{l}0.529 * * * \\
(0.188)\end{array}$ & $\begin{array}{l}0.085 \\
(0.185)\end{array}$ \\
\hline Elite Referee & $\begin{array}{l}0.093 \\
(0.088)\end{array}$ & $\begin{array}{l}0.058 \\
(0.087)\end{array}$ & $\begin{array}{l}0.213^{* *} \\
(0.106)\end{array}$ & $\begin{array}{l}0.185 * \\
(0.106)\end{array}$ & $\begin{array}{l}0.142 \\
(0.108)\end{array}$ & $\begin{array}{l}0.840 \\
(0.107)\end{array}$ \\
\hline Home Red & $\begin{array}{l}0.317^{* *} \\
(0.128)\end{array}$ & $\begin{array}{l}0.314^{* *} \\
(0.127)\end{array}$ & & & & \\
\hline Away Red & $\begin{array}{l}0.040 \\
(0.103)\end{array}$ & $\begin{array}{l}0.145 \\
(0.102)\end{array}$ & & & & \\
\hline Home Red / Yellow & $\begin{array}{l}-0.135 \\
(0.128)\end{array}$ & $\begin{array}{l}0.264^{* *} \\
(0.127)\end{array}$ & & & & \\
\hline Away Red / Yellow & $\begin{array}{l}0.299 * * * \\
(0.104)\end{array}$ & $\begin{array}{l}-0.107 \\
(0.103)\end{array}$ & & & & \\
\hline Home shots on goal & & & & & $\begin{array}{l}-0.049 \\
(0.055)\end{array}$ & $\begin{array}{l}0.032 \\
(0.055)\end{array}$ \\
\hline Away shots on goal & & & & & $\begin{array}{l}0.039 * \\
(0.020)\end{array}$ & $\begin{array}{l}0.004 \\
(0.020)\end{array}$ \\
\hline $\begin{array}{l}\text { Ratio of home possession } \\
\text { to away possession } \\
\text { (HPAP) }\end{array}$ & & & & & $\begin{array}{l}0.079 \\
(0.369)\end{array}$ & $\begin{array}{l}0.153 \\
(0.368)\end{array}$ \\
\hline $\begin{array}{l}\text { HPAP x Home shots on } \\
\text { goal }\end{array}$ & & & & & $\begin{array}{l}0.029 \\
(0.045)\end{array}$ & $\begin{array}{l}-0.007 \\
(0.045)\end{array}$ \\
\hline Home fouls & & & & & $\begin{array}{l}0.086^{* * *} \\
(0.010)\end{array}$ & $\begin{array}{l}0.015 \\
(0.010)\end{array}$ \\
\hline Away fouls & & & & & $\begin{array}{l}0.017^{* *} \\
(0.009)\end{array}$ & $\begin{array}{l}0.080 * * * \\
(0.009)\end{array}$ \\
\hline $\begin{array}{l}\text { Referee Nationality Fixed } \\
\text { Effects }\end{array}$ & \multicolumn{2}{|c|}{ INCLUDED } & \multicolumn{2}{|c|}{ INCLUDED } & \multicolumn{2}{|c|}{ INCLUDED } \\
\hline $\begin{array}{l}\text { Club Nationality Fixed } \\
\text { Effects }\end{array}$ & \multicolumn{2}{|c|}{ INCLUDED } & \multicolumn{2}{|c|}{ INCLUDED } & \multicolumn{2}{|c|}{ INCLUDED } \\
\hline Rho $(\rho)$ & \multicolumn{2}{|c|}{$0.222 * * *(0.025)$} & \multicolumn{2}{|c|}{$0.239 * * *(0.042)$} & \multicolumn{2}{|c|}{$0.207 * * *(0.043)$} \\
\hline $\begin{array}{l}\text { LR test (joint significance } \\
\text { of covariates) }\end{array}$ & \multicolumn{2}{|c|}{171.89} & \multicolumn{2}{|c|}{89.64} & \multicolumn{2}{|c|}{172.84} \\
\hline $\begin{array}{l}\text { LR test (independent } \\
\text { equations) }\end{array}$ & \multicolumn{2}{|c|}{72.40} & \multicolumn{2}{|c|}{29.77} & \multicolumn{2}{|c|}{21.40} \\
\hline $\mathrm{N}$ & \multicolumn{2}{|c|}{1720} & & & & \\
\hline
\end{tabular}

Notes: Models 2 and 3 based on Champions League data only. 
Table 6: Referee Nationality: Marginal Effects

Panel (a): Home Team Equation

\begin{tabular}{|l|l|l|l|l|l|l|}
\hline Nationality & 0 & 1 & 2 & 3 & 4 & 5 \\
\hline Austrian & $\mathrm{N} / \mathrm{S}$ & $\mathrm{N} / \mathrm{S}$ & $\mathrm{N} / \mathrm{S}$ & $\mathrm{N} / \mathrm{S}$ & $\mathrm{N} / \mathrm{S}$ & $\mathrm{N} / \mathrm{S}$ \\
\hline Belgian & 0.100 & 0.036 & -0.045 & -0.050 & -0.024 & -0.016 \\
\hline Danish & $\mathrm{N} / \mathrm{S}$ & $\mathrm{N} / \mathrm{S}$ & $\mathrm{N} / \mathrm{S}$ & $\mathrm{N} / \mathrm{S}$ & $\mathrm{N} / \mathrm{S}$ & $\mathrm{N} / \mathrm{S}$ \\
\hline English & $\mathrm{N} / \mathrm{S}$ & $\mathrm{N} / \mathrm{S}$ & $\mathrm{N} / \mathrm{S}$ & $\mathrm{N} / \mathrm{S}$ & $\mathrm{N} / \mathrm{S}$ & $\mathrm{N} / \mathrm{S}$ \\
\hline French & $\mathrm{N} / \mathrm{S}$ & $\mathrm{N} / \mathrm{S}$ & $\mathrm{N} / \mathrm{S}$ & $\mathrm{N} / \mathrm{S}$ & $\mathrm{N} / \mathrm{S}$ & $\mathrm{N} / \mathrm{S}$ \\
\hline German & $\mathrm{N} / \mathrm{S}$ & 0.024 & $\mathrm{~N} / \mathrm{S}$ & -0.028 & -0.014 & -0.010 \\
\hline Greek & -0.065 & -0.051 & 0.018 & 0.045 & 0.028 & $\mathrm{~N} / \mathrm{S}$ \\
\hline Italian & $\mathrm{N} / \mathrm{S}$ & $\mathrm{N} / \mathrm{S}$ & $\mathrm{N} / \mathrm{S}$ & $\mathrm{N} / \mathrm{S}$ & $\mathrm{N} / \mathrm{S}$ & $\mathrm{N} / \mathrm{S}$ \\
\hline Dutch & 0.081 & 0.032 & -0.036 & -0.042 & -0.020 & -0.014 \\
\hline Norwegian & 0.105 & 0.037 & -0.047 & -0.053 & -0.024 & -0.017 \\
\hline Portuguese & $\mathrm{N} / \mathrm{S}$ & $\mathrm{N} / \mathrm{S}$ & $\mathrm{N} / \mathrm{S}$ & $\mathrm{N} / \mathrm{S}$ & $\mathrm{N} / \mathrm{S}$ & $\mathrm{N} / \mathrm{S}$ \\
\hline Russian & 0.082 & 0.032 & $\mathrm{~N} / \mathrm{S}$ & -0.043 & -0.021 & -0.014 \\
\hline Scottish & 0.095 & 0.035 & -0.043 & -0.048 & -0.023 & -0.016 \\
\hline Slovakian & $\mathrm{N} / \mathrm{S}$ & $\mathrm{N} / \mathrm{S}$ & $\mathrm{N} / \mathrm{S}$ & $\mathrm{N} / \mathrm{S}$ & $\mathrm{N} / \mathrm{S}$ & $\mathrm{N} / \mathrm{S}$ \\
\hline Spanish & $\mathrm{N} / \mathrm{S}$ & $\mathrm{N} / \mathrm{S}$ & $\mathrm{N} / \mathrm{S}$ & $\mathrm{N} / \mathrm{S}$ & $\mathrm{N} / \mathrm{S}$ & $\mathrm{N} / \mathrm{S}$ \\
\hline Swedish & 0.086 & 0.033 & -0.038 & -0.044 & -0.021 & -0.015 \\
\hline Swiss & $\mathrm{N} / \mathrm{S}$ & $\mathrm{N} / \mathrm{S}$ & $\mathrm{N} / \mathrm{S}$ & $\mathrm{N} / \mathrm{S}$ & $\mathrm{N} / \mathrm{S}$ & $\mathrm{N} / \mathrm{S}$ \\
\hline
\end{tabular}

Panel (b): Away Team Equation

\begin{tabular}{|l|l|l|l|l|l|l|}
\hline Nationality & 0 & 1 & 2 & 3 & 4 & 5 \\
\hline Austrian & $\mathrm{N} / \mathrm{S}$ & $\mathrm{N} / \mathrm{S}$ & $\mathrm{N} / \mathrm{S}$ & $\mathrm{N} / \mathrm{S}$ & $\mathrm{N} / \mathrm{S}$ & $\mathrm{N} / \mathrm{S}$ \\
\hline Belgian & 0.073 & 0.065 & $\mathrm{~N} / \mathrm{S}$ & -0.047 & -0.042 & -0.041 \\
\hline Danish & $\mathrm{N} / \mathrm{S}$ & 0.045 & $\mathrm{~N} / \mathrm{S}$ & $\mathrm{N} / \mathrm{S}$ & -0.029 & -0.030 \\
\hline English & $\mathrm{N} / \mathrm{S}$ & $\mathrm{N} / \mathrm{S}$ & $\mathrm{N} / \mathrm{S}$ & $\mathrm{N} / \mathrm{S}$ & $\mathrm{N} / \mathrm{S}$ & $\mathrm{N} / \mathrm{S}$ \\
\hline French & $\mathrm{N} / \mathrm{S}$ & $\mathrm{N} / \mathrm{S}$ & $\mathrm{N} / \mathrm{S}$ & $\mathrm{N} / \mathrm{S}$ & $\mathrm{N} / \mathrm{S}$ & $\mathrm{N} / \mathrm{S}$ \\
\hline German & $\mathrm{N} / \mathrm{S}$ & $\mathrm{N} / \mathrm{S}$ & $\mathrm{N} / \mathrm{S}$ & $\mathrm{N} / \mathrm{S}$ & $\mathrm{N} / \mathrm{S}$ & $\mathrm{N} / \mathrm{S}$ \\
\hline Greek & -0.042 & -0.065 & $\mathrm{~N} / \mathrm{S}$ & 0.029 & 0.041 & 0.058 \\
\hline Italian & $\mathrm{N} / \mathrm{S}$ & $\mathrm{N} / \mathrm{S}$ & $\mathrm{N} / \mathrm{S}$ & $\mathrm{N} / \mathrm{S}$ & $\mathrm{N} / \mathrm{S}$ & $\mathrm{N} / \mathrm{S}$ \\
\hline Dutch & 0.063 & 0.058 & $\mathrm{~N} / \mathrm{S}$ & -0.041 & -0.037 & -0.037 \\
\hline Norwegian & $\mathrm{N} / \mathrm{S}$ & $\mathrm{N} / \mathrm{S}$ & $\mathrm{N} / \mathrm{S}$ & $\mathrm{N} / \mathrm{S}$ & $\mathrm{N} / \mathrm{S}$ & $\mathrm{N} / \mathrm{S}$ \\
\hline Portuguese & -0.044 & -0.065 & $\mathrm{~N} / \mathrm{S}$ & 0.029 & 0.041 & 0.058 \\
\hline Russian & 0.091 & 0.075 & $\mathrm{~N} / \mathrm{S}$ & -0.057 & -0.049 & -0.047 \\
\hline Scottish & $\mathrm{N} / \mathrm{S}$ & $\mathrm{N} / \mathrm{S}$ & $\mathrm{N} / \mathrm{S}$ & $\mathrm{N} / \mathrm{S}$ & $\mathrm{N} / \mathrm{S}$ & $\mathrm{N} / \mathrm{S}$ \\
\hline Slovakian & $\mathrm{N} / \mathrm{S}$ & $\mathrm{N} / \mathrm{S}$ & $\mathrm{N} / \mathrm{S}$ & $\mathrm{N} / \mathrm{S}$ & $\mathrm{N} / \mathrm{S}$ & $\mathrm{N} / \mathrm{S}$ \\
\hline Spanish & 0.047 & 0.046 & $\mathrm{~N} / \mathrm{S}$ & -0.031 & -0.030 & -0.031 \\
\hline Swedish & $\mathrm{N} / \mathrm{S}$ & 0.047 & $\mathrm{~N} / \mathrm{S}$ & -0.032 & -0.030 & -0.031 \\
\hline Swiss & $\mathrm{N} / \mathrm{S}$ & $\mathrm{N} / \mathrm{S}$ & $\mathrm{N} / \mathrm{S}$ & $\mathrm{N} / \mathrm{S}$ & $\mathrm{N} / \mathrm{S}$ & $\mathrm{N} / \mathrm{S}$ \\
\hline
\end{tabular}

Note: Estimates are significantly different from zero at the $10 \%$ level or better. N/S = not significant.

Columns represent the probability of awarding 0,1,2,3,4,5 disciplinary points. For example, the third cell of column 2 (Panel (a)) indicates that Belgian referees are 10\% more likely to issue zero disciplinary points to the home team. Estimates based on Model 4 (Table 4). 


\section{Appendix: Variable Definitions}

\begin{tabular}{|c|c|}
\hline Variables & Definition \\
\hline $\begin{array}{l}\text { Difference in Team } \\
\text { Coefficient Index }\end{array}$ & $\begin{array}{l}\text { Team Coefficient Index of Home Team Minus Team } \\
\text { Coefficient Index of the Away Team. }\end{array}$ \\
\hline $\begin{array}{l}\text { Stage of } \\
\text { Competition }\end{array}$ & $\begin{array}{l}=1 \text { if Round of } 32 \text { onwards (Round of } 16 \text { in the case of the } \\
\text { Champions League), } 0 \text { otherwise }\end{array}$ \\
\hline Champions League & $\begin{array}{l}=1 \text { if Champions League Match, } 0 \text { otherwise (i.e. UEFA Cup } \\
\text { match) }\end{array}$ \\
\hline Attendance / 1000 & Attendance scaled by 1000 \\
\hline $\begin{array}{l}\text { Attendance to } \\
\text { Capacity Ratio }\end{array}$ & Attendance divided by stadium capacity \\
\hline Track & $=1$ if stadium has a running track, 0 otherwise \\
\hline Fence & $=1$ if stadium has fencing, 0 otherwise \\
\hline Home Cards & Total disciplinary "points" issued to the home team \\
\hline Away Cards & Total disciplinary "points" issued to the away team \\
\hline Referee Nationality & $\begin{array}{l}\text { Dummy Variables which represent referee nationalities } \\
\text { (minimum of } 70 \text { observations required for inclusion). }\end{array}$ \\
\hline $\begin{array}{l}\text { Home Club } \\
\text { Nationality }\end{array}$ & $\begin{array}{l}\text { Dummy Variables which represent home club nationality } \\
\text { (minimum of } 70 \text { observations required for inclusion). }\end{array}$ \\
\hline $\begin{array}{l}\text { Away Club } \\
\text { Nationality }\end{array}$ & $\begin{array}{l}\text { Dummy Variables which represent the away club nationality } \\
\text { (minimum of } 70 \text { observations required for inclusion). }\end{array}$ \\
\hline ‘Big Five’ Home & $\begin{array}{l}=1 \text { if home club from one of the "big five" leagues }{ }^{\mathrm{a}}, 0 \\
\text { otherwise }\end{array}$ \\
\hline 'Big Five’ Away & $\begin{array}{l}=1 \text { if away club from one of the "big five" leagues }{ }^{\mathrm{a}}, 0 \\
\text { otherwise. }\end{array}$ \\
\hline Elite Referee & $\begin{array}{l}=1 \text { if match official officiated at the } 2004 \text { European } \\
\text { Championship, } 0 \text { otherwise. }\end{array}$ \\
\hline
\end{tabular}

Notes: ${ }^{a}$ Club from England, France, Germany, Italy or Spain. 